\title{
The Relationship Between Basic Sanitation and Personal Hygiene with The Incidence of Diarrhea In Medan City
}

\author{
Rina Amelia \\ Department of Public Health \\ Faculty of Medicine, Universitas Sumatera Utara \\ Jl. dr. Mansyur No.5 Kampus USU Medan, Indonesia 20155 \\ rina2@usu.ac.id
}

\begin{abstract}
Diarrhea is still a public health problem in developing countries. The availability of basic sanitation such as clean water, the use of latrines, the disposal of wastewater, the garbage disposal, the house and the healthy environment and the cultivation of clean and healthy living behaviors in daily life need to be done to prevent the increasing incidence of environmentbased diseases, including diarrhea. The purpose of this study was to analyze the relationship between basic sanitation consisting of the condition of the toilet building, the condition of landfills system, the condition of the sewerage system and the habit of hand washing with the incidence of diarrhea at Medan Labuhan Primary Health Care in Medan city. The population of this research is the community around Medan Labuhan Primary Health Care which is 15-55 years old. The sample of research is 65 people with consecutive sampling method. Data collection using primary data by interview and direct observation. Assessment of basic sanitation using observation with checklist guidance already valid, hand washing judgment assessment using interview with valid questionnaire guidance. Data analysis using chi square with SPSS program. The result showed that there was correlation between the condition of the toilet with the occurrence of diarrhea $(\mathrm{p}=0,002$, Prevalence Ratio $=8,9)$, there was correlation between the condition of household garbage with diarrhea occurrence $(\mathrm{p}=0,014$, Prevalence Ratio $=5,1)$, there was a relationship between the condition of sewerage system $(p=0,008$, $P R=4,6)$ and there is a relationship between hand washing habit and diarrhea occurrence in community at the The Medan Labuhan Primary Health Care $(p=0,005$, Prevalence Ratio= 12,5).
\end{abstract}

\section{Keywords - diarrhea; toilet building; landfills system; sewerage system; habit of hand washing}

\section{INTRODUCTION}

Diarrhea is still the leading cause of death in the world, accounting for 5-10 million deaths/year. The World Health Organization (WHO) estimates 4 billion cases worldwide and 2.2 million are dead, and most children are under 5 years old. According to data in America, each child has 7-15 episodes of diarrhea with an average age of 5 years. According to data in developing countries on average, each child under the age of 5 years experienced episodes of diarrhea three to four times per year [1]

In Indonesia, Diarrhea in addition to endemic diseases, are also potential diseases of outbreaks that are often accompanied by death. In 2015 there were 18 outbreaks of diarrhea spread in 11 provinces, 18 districts/cities, with the number of 1,213 people and 30 deaths (Casa Fatality Rate/CFR $=47 \%$ ). The highest number of outbreaks is in East Nusa Tenggara with 452 cases with a mortality rate of 6 people. The mortality rate when an outbreak of diarrhea is expected to be $<1 \%$. In $2011 \mathrm{CFR}$ when the outbreak $0.40 \%$, while in 2015 increased to $2.47 \%$. The estimated number of diarrhea sufferers coming to health facilities and health cadres is $10 \%$ of the morbidity rate multiplied by the number of residents in one work area within a year. National morbidity results from the Diarrhea Morbidity Survey of 2012 which amounted to $214 / 1.000$ population. It is estimated that the number of diarrhea sufferers in the health facility as much as $5,097,247$ people, while the number of diarrhea patients reportedly handled in health facilities as many as 4,017,861 people or $74.33 \%$ and the target of 5.405 .235 or $100 \%$ [2].

In North Sumatra, in 2014, the estimated number of cases was 294,611 cases, which were found and handled as many as $240,303(81 \%)$, so the rate of illness (IR) of diarrhea per 1.000 population reached 17.45 . This achievement has increased from the year 2013 which is $16,80 / 1.000$ and the year 2012 that is $16,36 / 1.000$. but this achievement decreased compared to the year 2011 which is $19.35 \%$ and 2010 is $19,73 \%$. This IR achievement is far below the program target of 214 per 1.000 population. The low IR is feared not to reflect the decrease in the incidence of diarrheal diseases in the community but more due to the many cases that are not recorded (under-reporting case) of the 33 districts/municipalities, prevention and treatment of diarrhea cases were highest in 3 districts that exceeded the estimated cases of Padang Lawas (476\%), Sibolga (170\%), and the north Labuhan Batu (163\%). Prevention and handling of the lowest diarrhea in West Nias District and Padang Sidempuan City are zero cases and North Nias District by $6 \%$ [3]. 
Behavioural awareness and community knowledge factors, availability of clean water sources, the availability of family latrines and the reach of health services need to be considered as factors affecting extraordinary events. The prevalence of diarrhea is more prevalent in rural than in urban areas. Diarrhea tends to be higher in the lower education group [4]. According to Kepmenkes No 852/Menkes/SK/IX/2008 on the national strategy of sanitation [5], basic sanitation includes defecation, waste management, and household waste. Based on the study of Basic Human Service (BHS) in Indonesia in 2006, shows that the behaviour of people in hand washing after $12 \%$ defecation, after cleaning the baby's faeces and toddler $9 \%$, before eating $14 \%$, before feeding baby $7 \%$ and before preparing food $6 \%$. While the results of other BHS studies of household drinking water treatment behaviours showed $99,22 \%$ boiling water to get drinks, but $47.50 \%$ of the water still contained Escherichia coli [6].

Hand washing with soap behaviour can reduce the incidence of diarrhea by $47 \%$ and $23 \%$ of respiratory infections [7]. Dirty or contaminated hands can cause pathogenic bacteria and viruses from the body, faeces or other sources of food. There fore hand hygiene by hand washing needs to be given high priority, although it is often underestimated. Washing with soap as a cleanser, scrubbing, and flushing with running water will incite dirt particles that contain lots of microorganisms [8]. The purpose of this study was to analyze the relationship of basic house sanitation and handwashing with soap with diarrhea occurrence in the work area of Medan Labuhan Public Health Care (PHC) in Medan city.

\section{METHOD}

The research design is an analytical study with crosssectional approach. The population of this research is the community in the work area of Medan Labuhan Subdistrict Medan Belawan. The sample of research as many as 65 people determined by consecutive sampling. Sources of research data are primary and secondary data. Primary data obtained through interviews and direct observation with the guidelines sheet checklist. The checklist sheet is used to get an overview of basic home sanitation facilities from respondents through direct observation. Secondary data is the medical record of Medan Labuhan PHC. Collected data were analysed by using SPSS and data analysis with the chi-square test.

The condition of toilet building was measured by observation using checklist sheet. The toilet criteria that meet the health standards and requirements are: (a). There is a septic tank; (b). Does not contaminate surface water; (c). Distance to the source of clean water is approximately ten meters; (d). The type of toilet used should meet the following criteria: (1). if the swan neck of the insulating water always closes the hole where squats and (2). If without a goose-neck is equipped with a hole cover where squats; and (e). Around the pit are clean and odourless.

The condition of household waste is measured by observation using checklist sheet. Criteria for landfills system that meet health requirements are: (a). Being close to garbage producers; (b). Always closed; (c). Made from the water-proof material, and D). Not a breeding ground/ infestation of infectious diseases such as flies and cockroaches. The Sewerage system is measured by means of observation using a checklist sheet.

The Sewerage system must meet the following health requirements: (a). Closed and not open; (b). Does not pollute the source of clean water; (c). Current and does not cause puddles (d) Does not cause odours; and (e). Does not cause muddy.

The Habit of Hand washing with Soap is measured by interview using a checklist sheet. Habits performed by respondents in cleaning hands and fingers using water and soap after defecation and before eating. Diarrhea history was assessed from respondents who experienced diarrhea to treatment at Medan Labuhan PHC as evidenced by medical records.

\section{RESULT}

\section{A. Description of Respondent's Characteristic.}

TABLE I

RESPONDENT CHARACTERISTICS

\begin{tabular}{|c|c|c|}
\hline Characteristics & Frequency & Percentage (\%) \\
\hline Age group & & \\
\hline $15-24$ years old & 12 & 18,4 \\
\hline $25-35$ years old & 27 & 41,6 \\
\hline $36-45$ years old & 18 & 27,7 \\
\hline 46 - 55 years old & 8 & 12,3 \\
\hline Gender & & \\
\hline Man & 8 & 12,3 \\
\hline Women & 57 & 87,7 \\
\hline Level of education & & 9,2 \\
\hline Not completed in & 6 & 35,4 \\
\hline Elementary school & & 26,2 \\
\hline Elementary school & 23 & 24,6 \\
\hline Junior high school & 17 & 4,6 \\
\hline Senior high school & 16 & \\
\hline Academic & 3 & 1,5 \\
\hline Work & 9,2 \\
\hline Farmers & & 4,6 \\
\hline Entrepreneurship & 6 & 6,2 \\
\hline Private employees & 3 & 78,5 \\
\hline Civil servants & 4 & 52,3 \\
\hline House wife & 51 & $\mathbf{1 0 0}$ \\
\hline Diarrhea Occurrence & & \\
\hline Yes & 31 & \\
\hline No & $\mathbf{6 5}$ & \\
\hline Total & & \\
\hline
\end{tabular}

Based on table 1 it is known that most age groups in this study are 25-35 years old as many as 27 people (41.6\%), based on the gender of the majority of women 57 people $(87,7 \%)$, based on the educational level majority of respondents are graduated from elementary school 23 (35.4\%), based on the work of the majority of respondents are house wife 51 people $(78.5 \%)$ and diarrhea incidence is known that 
more respondents who did not experience the history of diarrhea that ultimately went to the health center as many as 34 people $(52.3 \%)$

\section{B. The Relationship of Basic Sanitation and Hygiene with Diarrhea Occurrence}

TABLE II

SANITATION AND HYGIENE RELATIONSHIPS WITH DIARRHEA OCCURRENCE

\begin{tabular}{|c|c|c|c|c|c|c|}
\hline \multirow{2}{*}{$\begin{array}{l}\text { Hygiene and } \\
\text { Sanitation }\end{array}$} & \multicolumn{4}{|c|}{ Diarrhea } & \multirow[t]{2}{*}{$p$} & \multirow[t]{2}{*}{ PR } \\
\hline & Yes & $\%$ & No & $\%$ & & \\
\hline \multicolumn{7}{|c|}{$\begin{array}{l}\text { Building Condition } \\
\text { of Toilet }\end{array}$} \\
\hline Not eligible & 29 & 44,6 & 21 & 32,3 & \multirow{2}{*}{0,002} & \multirow{2}{*}{8,9} \\
\hline Qualify & 2 & 3,1 & 13 & 20 & & \\
\hline \multicolumn{7}{|l|}{$\begin{array}{l}\text { Condition of } \\
\text { landfills System }\end{array}$} \\
\hline Not eligible & 28 & 43,1 & 22 & 33,8 & \multirow{2}{*}{0,014} & \multirow{2}{*}{5,1} \\
\hline Qualify & 3 & 4,6 & 12 & 18,5 & & \\
\hline \multicolumn{7}{|c|}{$\begin{array}{l}\text { Condition of } \\
\text { Sewerage System }\end{array}$} \\
\hline Not eligible & 26 & 83,9 & 18 & 52,9 & \multirow{2}{*}{0,008} & \multirow{2}{*}{4,6} \\
\hline Qualify & 5 & 16,1 & 16 & 47,1 & & \\
\hline \multicolumn{7}{|c|}{$\begin{array}{l}\text { Habit of } \\
\text { Handwashing with } \\
\text { Soap }\end{array}$} \\
\hline Not eligible & 30 & 46,2 & 24 & 36,9 & \multirow{2}{*}{0,005} & \multirow{2}{*}{12,5} \\
\hline Qualify & 1 & 1,5 & 10 & 15,4 & & \\
\hline
\end{tabular}

The results of table 2 can be seen that most of the sample is in the condition of the toilet building which does not fulfill the requirement that is 50 people $(76,9 \%)$ with the person experiencing the diarrhea condition in the unqualified toilet condition is 29 people $(44,6 \%)$, and those who did not experience the incidence of diarrhea were 21 people $(32.3 \%)$. Based on chi-square test, it is known that $p=0,002(p<0,05)$ means that there is a significant relationship between the condition of the toilet building with the incidence of diarrhea in the community at Medan labuhan health center, it is known that PR value (Prevalence Ratio) $=8,9$ can be concluded the condition of the toilet building becomes the risk of occurrence of diarrhea, the magnitude of the risk is 8.9 times (people who have unqualified toilet buildings have a risk of diarrhea 8.9 times greater than those with eligible toilet buildings.

Based on the condition of landfills system which is 50 people $(76,9 \%)$ with people having diarrhea condition in unqualified landfills System is 28 people $(43,1 \%)$, and those that do not experience diarrhea incident are 22 people $(33.8 \%)$. Based on chi square test, it is known that $p=0,014(p<0,05)$ means that there is a significant correlation between landfills system condition and diarrhea occurrence in the community at Medan labuhan health center, it is known that $P R$ value $=5,1$ can be concluded the condition of landfills system condition becomes the risk of occurrence of diarrhea, the magnitude of the risk is 5.1 times (people who have a landfills system condition that is not eligible have a risk of diarrhea 8.9 times greater than that which has a condition of landfills system qualify.

Based on the condition of sewerage system (SS), it is known that most of the sample in the condition of SS that does not meet the requirement is 44 people $(67,7 \%)$ with the person having diarrhea condition in unqualified SS is 26 person $83.9 \%$ ), and those who did not experience diarrhea incidence were 18 people $(52.9 \%)$. Based on chi-square test, $\mathrm{p}=0,08$ $(\mathrm{p}<0,05)$ means that there is a significant relationship between SS and the incidence of diarrhea in the community at Medan labuhan health center, it is known that PR value $=4,6$ can be concluded SS is the risk of diarrhea, the magnitude of the risk is 4.6 times (people who have an unsuitable SS condition have a 4.6 times greater risk of diarrhea than those with a qualified SS condition

Based on the habit of washing hands with soap that do not meet the requirements of 54 people $(83.1 \%)$ with people who experienced diarrhea events in the condition of washing hands is not eligible is 30 people $(46.2 \%)$, and who do not experience diarrhea is 24 people $(36.9 \%)$. Based on chi-square test known that $\mathrm{p}=0,005(\mathrm{p}<0,05)$ meaning there is a significant relationship between handwashing habits with the incidence of diarrhea in the community at Medan labuhan health center, known PR value (Prevalence Ratio) $=12,5$ can be concluded habit of washing the hand becomes a risk of diarrhea, the magnitude of the risk is 12.5 times (people who have a habit of hand washing is not eligible to have a risk of diarrhea 12.5 times greater than the hand-washing habits are eligible.

\section{IV.DISCUSSION}

\section{A. The Relationship between the Condition of the Toilet Building and the Event of Diarrhea}

The result showed that there was a correlation between building condition of the toilet with diarrhea occurrence ( $p$ $<0,05)$ the amount of building condition risk for occurrence of diarrhea was 8,9. Another study result that there is a relationship between unqualified toilet conditions against the occurrence of diarrhea [9]. Unqualified latrine building conditions are 7 times more risky to cause diarrheal disease and a risk factor for diarrhea [10]. The distance between the dung holes with clean water sources or wells that are less than 10 meters, will cause germs from diarrheal diseases that contaminate the sources of clean water used by people for everyday purposes [11]. Wastewater discharge conditions that do not meet health requirements may potentially lead to diarrheal diseases as they will easily seep into clean water sources causing pollution [12].

\section{B. Relationship Between Landfills System Condition with Diarrhea Occurrence}

The result showed that there was the correlation between landfills system condition with diarrhea occurrence $(p<0,05)$, 
the risk of landfills system condition for diarrhea 5.1. The results of this study are in line with research conducted in Miri Sub-district Sragen Regency where there is a relationship between the condition of landfills system with diarrhea occurrence [10]. In order to prevent the occurrence of vector congenital diseases that multiply in the waste, the dump must meet the criteria of health requirements, among others: (1) The garbage collection in a garbage can not exceed 48 hours, and immediately disposed of; (2) Placement of trash should be placed at the nearest distance which generates a lot of waste; (3) Waste bin should not be a breeder/breeding ground for insects or vector animals (4) We recommend a waterproof garbage bin, so that the wet garbage does not splatter so invite the arrival of flies [13].

\section{Relationship between Sewerage System Condition with Diarrhea Occurrence}

The results showed that there is a significant relationship between sewerage system condition with the incidence of diarrhea in the community at Medan labuhan clinic, sewerage system become the risk of diarrhea, the magnitude of the risk is 4.6. The results of this study are in line with another study that there is a relationship between the sewerage channel against the occurrence of diarrhea [14]. This is because there are still many unqualified sewerage discharges such as the number of households discharging household waste to open and uncovered channels of $76.9 \%$. Based on the result of research indicate from case respondent (diarrhea suffering) $43,1 \%$ condition of sewerage channel still open, not smooth, causing puddle of water / muddy, and cause odor.

Creating a closed sewerage system and always maintaining sewerage system is an effort that can be done to prevent the media transmission of diarrheal diseases [15]. The condition of sewerage discharges that do not meet the health requirements can potentially lead to diarrheal diseases because this sewerage will easily seep into clean water sources causing pollution [12]. In addition, the sewerage sewer that is left open, non-current, and muddy will easily become a breeding ground for microorganisms or living creatures and vectors that cause diarrheal diseases. The sewerage which does not smooth or cause puddles, will cause odor, disturbing aesthetics, and can be the culprit of the culprit vectors disease, this condition can potentially transmit the disease [16]. To prevent things, it should be a closed sewerage sewer, its construction made of cement, and channeled into a wastewater disposal facility. Water household waste is the wastewater coming from the room's wastewater bathing, kitchen activities, laundry, and so on pathogenic microorganisms that can harm health, one of them diarrheal diseases.

\section{The Relationship between Handwashing Habits and Soap with Diarrhea}

In this study, hand washing habits meet the requirements are risk factors for diarrhea, the results of this study in accordance another research that respondents who do not have a habit of washing hands with soap more risk 7 times causing diarrhea disease and is a risk factor for diarrhea [10] [17]. This is influenced by the low knowledge of the population of the importance of washing hands before and after meals, using soapy water and wiping the remaining hand washing water with disposable cloth or disposable tissue paper, indicating that unqualified hand washing habits are still found at $83.1 \%$ of the population.

\section{CONCLUSION}

Based on the result of research and discussion, it can be concluded that there is a correlation between the condition of the toilet building, the condition of landfills system, the condition of the sewage disposal channel system and the habit of hand washing with soap diarrhea in the work area of Medan Labuhan PHC. Health promotion and dissemination of information on a regular basis is important especially on basic home sanitation and hand washing with soap in order to increase knowledge and reduce the risk of diarrheal diseases in the community especially in high-risk areas such as those with lower middle-income socio-economic conditions.

\section{REFERENCES}

[1] World Health Organization. "Indicators to Improve Children's Environmental Health" Transl. Apriningsih ; Jakarta: EGC.

[2] Ministry of Health of the Republic of Indonesia. "Indonesia Health Profile 2015" Directorate General of Disease Control \& Environmental Health. Kementerian Kesehatan Republik Indonesia.

[3] Provincial Health Office of North Sumatra. 2015. Health Profile of North Sumatera Province Year 2014.

http://www.depkes.go.id/resources/download/profil/PROFIL_KES_PR OVINSI 2014/02_Profil_Kes_Prov.SumateraUtara_2014.pdf [accessed 06 Juni 2017].

[4] Ministry of Health Republic of Indonesia, 2013. "Basic Health Research". Agency for Health Research and Development Ministry of Health RI.

[5] Ministry of Health of the Republic of Indonesia. "Decree of the Minister of Health No. 852 / MENKES / SK / IX / 2008 on National Strategy of Total Community Based Sanitation (NSTCBS)"

[6] Aithal, K. S., Ogorchukwu, M. J., Vidya, P., Prafulla, S., \& Yadav, U. N. "Hand Washing Knowledge and Practice Among Mothers of UnderFive Children in Coastal Karnataka, India- A Cross-Sectional Study". International Journal of Medical and Health Sciences, Vol 3, Issue 4, Oct 2014, pp 266-271.

[7] Rosidi, A. "The Relationship of Handwashing Habits and Food Sanitation with Diarrhea Occurrences in Elementary School Children of Podo 2 Kedungwuni District of Pekalongan Regency," Journal of Public Health Indonesia, Vol 6, Number 1, Year 2010, pp.76-84.

[8] Nurjanah. Relationship between Sanitation and Hygiene with Diarrhea Events in Pamotan Rembang Village Year 2010, Thesis: State University of Semarang.

[9] Sugiarto, K.T. "The relationship between basic home sanitation facilities and handwashing habits with soap with diarrhea occurrence in the work area of Miri Health Center Sragen regency, in 2010. Thesis: State University of Semarang.

[10] Mafazah, L. "Availability of Basic Sanitation Means, Personal Hygiene of Mothers and Diarrhea Occurrences," Journal of Public Health UNNES, Vol 8, No. 2, Year 2013, pp 176-182

[11] Taosu, S. A., Azizah, R. "Relationship of Basic Household Sanitation and Housewife Behavior with Diarrhea Occurrence in Toddlers in Bena Nusa Tenggara Timur Village. Journal of Environmental Health. 2013: 7 (1); 1-6. 
[12] Sragen District Health Office. "Profile of Health Office of Sragen Regency", 2012. Sragen.

[13] Sudasman, FH. "Ownership Relationship of Household Basic Sanitation Means, Personal Hygiene of Toddlers and Habit of Snack on Diarrhea Disease History, 2014."

[14] Suraatmaja, S. "Kapita Selekta Gastroenterology of Children. Jakarta, 2007 ": Sagung Seto.

[15] Nurjanah. Relationship between Sanitation and Hygiene with Diarrhea Events in Pamotan Rembang Village Year 2010, Thesis: State University of Semarang.

[16] Nurjanah. Relationship between Sanitation and Hygiene with Diarrhea Events in Pamotan Rembang Village Year 2010, Thesis: State University of Semarang.

[17] Rosyidah, AN. "Relationship of Handwashing Behavior to Diarrhea Occurrence at Students at Ciputat State Elementary School 02, Thesis: UIN Syarif Hidayatullah Jakarta. 2014 